Egyptian Journal of Aquatic Biology \& Fisheries

Zoology Department, Faculty of Science,

Ain Shams University, Cairo, Egypt.

ISSN $1110-6131$

Vol. 24(6): 331 - 341 (2020)

www.ejabf.journals.ekb.eg

\title{
Functional properties and proximate compositions of bony barb
}

protein hydrolysated

\author{
Junianto ${ }^{1}$, Eddy Afrianto ${ }^{1}$ and Zahidah Hasan ${ }^{1, *}$ \\ Department of Fisheries, Faculty of Fisheries and Marinel Sciences, Universitas Padjadjaran. \\ Jl. Raya Jatinangor, KM 21, Sumedang, West Java, Indonesia. \\ *Corresponding Author: junianto@unpad.ac.id; anto_lisc@yahoo.com
}

\section{ARTICLE INFO}

Article History:

Received: Jan. 20, 2020

Accepted: Aug. 30, 2020

Online: Sept. 2020

Keywords:

Bonylip barb;

Functional properties;

Papain;

Protein hydrolysate;

Proximate composition

\begin{abstract}
Bonylip barb is a fish of Indonesian origin lower in economic value than introduced fishes like catfish and Nile tilapia. The fish's added value may be improved by subjecting it to a process which is aimed to derive its protein hydrolysate. The purpose of this research was to determine the functional properties and proximate composition of bonylip barb protein hydrolysate flour. Bonylip barb protein hydrolysate flour was produced by, first, grinding of the bonylip fish, then by hydrolysis with $5 \%(\mathrm{w} / \mathrm{w})$ papain at 55 ${ }^{\circ} \mathrm{C}$ at $\mathrm{pH} 7$ for 6 hours and by centrifugation at $5,000 \mathrm{rpm}$ at $4{ }^{\circ} \mathrm{C}$ for 20 minutes, with the supernatant resulted being freeze-dried. The bonylip barb protein hydrolysate flour produced was observed for the functional properties, proximate composition, and amino acid profile. The research results show that the bonylip barb protein hydrolysate flour's scores for the functional properties of water absorption, oil absorption, emulsifying capacity, bulk density, and solubility in water were $3.1 \mathrm{~mL} / \mathrm{g}, 1.94 \mathrm{~mL} / \mathrm{g}$, $23.60 \%, 0.83 \mathrm{~g} / \mathrm{mL}$, and $78.2 \%$, respectively. The bonylip barb protein hydrolysate flour contained water, protein, fat, and ash at $8.75 \%, 84.65 \%$, $1.02 \%$, and $4.80 \%$, respectively.
\end{abstract}

\section{INTRODUCTION}

Indonesia is rich in fish diversity, with roughly 8,500 fish species existing in its territory (Nugroho et al., 2012). Some of the fish are native to the country, but some others are introduced from overseas. One of the fishes of Indonesian origin currently under developed cultivation is bonylip barb (Osteochilushasselti), called nilem in Indonesia.

Bonylip barb is an herbivorous freshwater fish which feeds on algae (Syamsuri $\boldsymbol{e t}$ al., 2017). Morphologically speaking, the fish is similar to common carp, with the tip of its mouth pointy-shaped and the snout folded, whose corners of the mouth are adorned with a pair of protrusions (Rostika et al., 2017). 
Bonylip barb possesses some comparative advantages over other cultivated fishes, namely resistance to diseases, high egg-productivity, and ability to spawn multiple times year-round. However, these comparative advantages are not offset by the competitive ones. As a fish for human consumption, bonylip barb is sold at a lower price than common fish, catfish, and Nile tilapia are. As food, it is less favored due to being bony. It is also less used as minced fish for having thin flesh.

To improve the added value of the fish, appropriate processing is necessary, for example, the processing into protein hydrolysate. Fish protein hydrolysate is a product of protein hydrolysis from fish as a raw material by either autolysis, thermal hydrolysis, or enzymatic hydrolysis (Villamil et al., 2017). Enzymatic hydrolysis, in particular, is presently more widely applied than any other techniques (Halim et al. 2016), while papain is the commercial enzyme most commonly used in fish protein hydrolysis (Chalamaiah et al., 2012).

Fish protein hydrolysate is a product that contains bioactive peptides with a low molecular weight and free amino acids (Villamil $\boldsymbol{e t}$ al., 2017). This product carries a wide variety of benefits, both food and non-food. The amino acids contained in protein hydrolysate are highly beneficial for various physiological functions of the human body and serve as an anti-oxidant agent against free radicals and as an anti-hypertension agent (Halim et al., 2016). Thus, this product arises with a high added value.

Functional properties such as water absorption, oil absorption, and emulsifying capacity of fish protein hydrolysates are highly dependent on what raw material is used (Nesse et al., 2014 and Annisa et al., 2017), and so is the proximate composition of fish protein hydrolysate (Kristinsson and Rasco, 2010). Hence, this research was conducted to determine the functional properties and proximate composition of bonylip barb protein hydrolysate flour.

\section{MATERIALS AND METHODS}

\section{Materials preparation}

Ten $\mathrm{kg}$ of bonylip barbs, 250 grams per fish, were extracted from the fish cultivation pond of Technical Implementing Unit of the Office of Marine Affairs and Fisheries of West Java. The pond was situated in Jati Village, Bojong Picung District, Cianjur Regency, $65 \mathrm{~km}$ away from the campus of Universitas Padjadjaran Jatinangor. The fishes were transported to the Laboratory of Fishery Product Processing of the Faculty of Fisheries and Marine Science, Universitas Padjadjaran, for filleting and grinding with a meat grinder. The ground bonylip barb meat was plastic-wrapped and stored in a freezer until it became ready for hydrolysis or production of fish protein hydrolysate. 


\section{Procedure of fish protein hydrolysate production}

The procedure of bonylip barb protein hydrolysate production based on Annisa et al., (2017) (modified method) was as follows:

- 100 grams of ground bonylip barb meat was inserted into a 1,000 ml beaker glass and added with $400 \mathrm{~mL}$ of distilled water to form a ground-meat-to-distilled-water ratio of $1: 4$. Prior to the insertion of the ground meat into the beaker glass, 5 grams $(5 \% \mathrm{w} / \mathrm{w})$ of "PAYA" brand commercial papain with an enzymatic activity of $1.0593 \mathrm{U} / \mathrm{g}$ was added first.

- The beaker glass, along with the mixture of the enzyme, ground meat, and distilled water, was placed into a waterbath for hydrolysis. The hydrolysis temperature was set at $55{ }^{\circ} \mathrm{C}$. Over the course of the hydrolysis, the $\mathrm{pH}$ was maintained at \pm 7 by applying $\mathrm{CH}_{3} \mathrm{COOH}$ if the $\mathrm{pH}$ went upward of 7 and $\mathrm{NaOH}$ if it went in the opposite direction.

- Hydrolysis was then performed aerobically for 6 hours, with stirring performed once every 2 hours.

- Afterwards, the papain enzyme was inactivated at $80{ }^{\circ} \mathrm{C}$ for 20 minutes to put the hydrolysis process to an end. The sample was centrifuged at $5,000 \mathrm{rpm}$ at $4{ }^{\circ} \mathrm{C}$ for 20 minutes to separate the supernatant from the pellet. The supernatant was dried by freeze-drying.

- The protein hydrolysate powder produced was stored within a closed container.

\section{Observation}

Observation was performed on the functional properties and proximate composition of the amino acids contained in the bonylip barb protein hydrolysate flour. The parameters for the functional properties included the water absorption, oil absorption, bulk density, emulsifying capacity, and solubility in water, whereas for the proximate composition the parameters included water content, ash content, protein content, lipid content, and carbohydrate content.

The procedure for the water absorption testing was as follows (Rieuwpassa et al., 2013). The bonylip barb protein hydrolysate flour sample was weighed at 1 grams, then inserted into a centrifuge tube, added with $10 \mathrm{~mL}$ of water. The mixture was stirred until mixed well, then left for 30 minutes at room temperature. Next, the mixture was centrifuged at 3,000 rpm for 30 minutes at room temperature. The water phase resulted was measured for the volume with a graduated cylinder as the unabsorbed water volume. The calculation for the water absorption was as follows:

- Water absorption $(\mathrm{mL} / \mathrm{g})=($ initial water volume - unabsorbed water volume $)$ : sample weight)

The procedure for the oil absorption testing was as follows (Rieuwpassa et al., 2013). The bonylip barb protein hydrolysate flour sample was weighed at 1 grams, then inserted into a centrifuge tube, added with $10 \mathrm{~mL}$ of palm oil. The mixture was stirred until mixed well, then left for 30 minutes at room temperature. Next, the mixture was 
centrifuged at 3,000 rpm for 30 minutes at room temperature. The oil phase resulted was measured for the volume with a graduated cylinder as the unabsorbed oil volume. The calculation for the oil absorption was as follows:

- Oil absorption $(\mathrm{mL} / \mathrm{g})=($ initial oil volume - unabsorbed oil volume $):$ sample weight

The procedure for the bulk density testing was as follows (modified from Wani $\boldsymbol{e t}$ al., 2013). The bonylip barb protein hydrolysate flour sample was weighed at 10 grams, then inserted into a $50 \mathrm{~mL}$ graduated cylinder for the volume measurement. The calculation for the bulk density was as follows:

- Bulk density $(\mathrm{g} / \mathrm{mL})$ = bonylip barb protein hydrolysate flour weight : bonylip barb protein hydrolysate flour volume

The procedure for the emulsifying capacity testing was as follows (Rieuwpassa $\boldsymbol{e t}$ al., 2013). The bonylip barb protein hydrolysate flour sample was weighed at 1 grams, then inserted into a centrifuge tube. Four $\mathrm{mL}$ of distilled water was then added to the centrifuge tube, which was then shaken for 1 minute. Then, $4 \mathrm{~mL}$ of maize oil was added too, and then the tube was shaken for 1 minute. Next, the sample-water-oil mixture was centrifuged at 6,000 rpm for 5 minutes at room temperature. The emulsion resulted was recorded. The calculation for the emulsifying capacity was as follows:

- Emulsifying capacity $(\%)=($ volume of the cream produced : initial volume $) \times 100$

The procedure for the testing of solubility in water was as follows (Rieuwpassa $\boldsymbol{e t}$ al. 2013). The bonylip barb protein hydrolysate flour sample was weighed at 0.75 grams, then solved into $150 \mathrm{~mL}$ of water (neutral $\mathrm{pH}$ ) in a $250 \mathrm{~mL}$ Erlenmeyer flask. The solution was then filtered with a piece of Whatman filter paper. The filter paper was previously oven-dried at $100{ }^{\circ} \mathrm{C}$ for 30 minutes and weighed. The filter paper along with the precipitate was oven-dried at $100{ }^{\circ} \mathrm{C}$ for 3 hours, then cooled in a desiccator and weighed. The calculation for the solubility in water was as follows:

- Solubility $(\%)=(($ bonylip barb protein hydrolysate flour weight - precipitate and filter paper weight - filter paper weight) : bonylip barb protein hydrolyste flour weight) $\times 100$

The procedure for the testing of composition proximate and total amino acids of the bonylip barb protein hydrolysate flour according to the method by the Association of Official Agricultural Chemists (AOAC) (Lee et al., 2016) was as follows. The water content was determined by placing accurately 0.2 grams of sample into an aluminum pan. The sample was dried in a forced-air convection oven at $105^{\circ} \mathrm{C}$ until a constant weight was reached. The ash content was determined by charring approximately 0.1 grams of sample in a ceramic crucible over a hot plate and then heating in a muffle furnace at 550 ${ }^{\circ} \mathrm{C}$ until a constant final weight for ash was achieved. The total crude protein (nitrogen $\times$ 6.25) content of the sample was determined using the semi-micro Kjeldahl method. Total lipid content was determined according to the Soxhlet extraction method. Five grams of sample was extracted with dimethyl ether for $30 \mathrm{~min}$ at a drip rate of $10 \mathrm{~mL} / \mathrm{min}$. Total 
lipid content was determined on a gravimetric basis and expressed as percent. Total amino acid analysis was determined by hydrolysis of the sample with $2 \mathrm{~mL}$ of $6 \mathrm{~N} \mathrm{HCl}$ at $110{ }^{\circ} \mathrm{C}$ for $24 \mathrm{~h}$ in a heating block, which was filtered out using a vacuum filtrator. Amino acids were quantified using the amino acid analyzer employing sodium citrate buffers ( $\mathrm{pH} 2.2$ ) as step gradients. The data were reported as $\mathrm{g}$ of amino acid per $100 \mathrm{~g}$ of protein. Asparagine was converted to aspartic acid, and glutamine to glutamate, during the acid hydrolysis, so the reported values for these amino acids (Asp and Glu) represent the sum of the respective amine and amino acid in the proteins.

Data analysis

The data collected from all observation variables were analyzed in a descriptivecomparative manner.

\section{RESULTS AND DISCUSSION}

1. Functional properties of bonylip barb protein hydrolysate flour

It is of a considerable importance that the functional properties of fish protein hydrolysate flour be identified, in particular if the product is to be used as a food ingredient (Kristinsson and Rasco, 2010). Functional properties are the intrinsic physicochemical properties which influence the behavior of a product during the preparation, processing, storage, and consumption (Chandra et al., 2015). The use of fish hydrolysate flour will be determined to a great extent by the functional properties (Foh $\boldsymbol{e} t$ al., 2011). The results of the bonylip barb protein hydrolysate flour functional properties analysis are presented in Table $\mathbf{1 .}$

Table 1. Functional properties of bonylip barb protein hydrolysate flour

\begin{tabular}{|l|c|}
\hline \multicolumn{1}{|c|}{ Parameter } & Bonylip barb protein hydrolysate flour \\
\hline Water absorption $(\mathrm{mL} / \mathrm{g})$ & 3.1 \\
Oil absorption $(\mathrm{mL} / \mathrm{g})$ & 1.94 \\
Bulk density $(\mathrm{g} / \mathrm{mL})$ & 0.83 \\
Emulsifying capacity $(\%)$ & 23.60 \\
Solubility in water $(\%)$ & 78.20 \\
\hline
\end{tabular}

Water absorption of bonylip barb protein hydrolysate flour is the ability of bonylip protein hydrolysate flour to absorb water. The factors influencing the water absorption of a product are the product's chemical composition and particle size (Ntau et al., 2017). The water absorption of the bonylip barb protein hydrolysate flour measured $3.1 \mathrm{~mL} / \mathrm{g}$ (Table 1), which was greater than the protein hydrolysate flour from Nile tilapia (2.1 $\mathrm{mL} / \mathrm{g}$; Foh et al., 2011) but smaller than that from the internals of rainbow trout (5.1 $\mathrm{mL} / \mathrm{g}$; Taheri et al. 2013). According to Mohammed et al. (2014), high-water-absorption protein hydrolysate products are much needed as a mixing material in the processing of sausage, and bakery for the texture formation. Water absorption arises due to the 
interaction of proteins to water in the presence of polar amino acid groups such as the carbonyl, hydroxyl, amino, carboxyl, and sulfydryl groups (Haryati et al., 2020). The more the free amino acids are produced in a hydrolysis process, the more reduced the hydrolysate flour's ability to bind water is (Halim et al., 2016).

Oil absorption of bonylip barb protein hydrolysate flour is the ability of bonylip barb protein hydrolysate flour to absorb oil. The protein hydrolysate flour's ability to absorb oil is highly influenced by the protein surface hydrophobicity (Kristinsson and Rasco. 2010). The oil absorption of the protein hydrolysate flour from bonylip barb (1.94 $\mathrm{mL} / \mathrm{g}$; Table 1) was lower than that from Nile tilapia $(2.27 \mathrm{~mL} / \mathrm{g}$; Foh et al., 2011). The oil absorption of protein hydrolysate flour contributes a great deal to the taste and palatability of a product in the food industry (deSantos, 2011).

Bulk density plays a significant role in the packaging, storage, and transport processes of a product (Foh et al., 2011). It is a ratio of the product's weight to the volume it occupies (Rieuwpassa et $\boldsymbol{a l}$., 2013). The bulk density value of the protein hydrolysate flour from bonylip barb $(0.83 \mathrm{~g} / \mathrm{mL}$; Table 1) was higher than that from Nile tilapia ( $0.45 \mathrm{~g} / \mathrm{mL}$; Foh et al., 2011). The smaller a product's value of bulk density, the more bulky the product is. A bulky product has a large porosity (Atmaka and Sigid. 2010), thus requiring more space for the storage. The bulk density of powdery products generally ranges from $0.3 \mathrm{~g} / \mathrm{mL}$ to $0.8 \mathrm{~g} / \mathrm{mL}$.

Emulsifying capacity is the ability to absorb water and oil equally. Bonylip barb protein hydrolysate flour has the ability to absorb water and oil due to its dominating protein component. As stated by Kaushal et al. (2012), protein contains two active groups: hydrophilic and lipophilic groups. The hydrophilic group is able to bind to or capture water, while the lipophilic group bind to or capture oil.

The emulsifying capacity of bonylip barb protein hydrolysate flour measured $23.60 \%$. This value is smaller than that of the protein hydrolysate flour from African sharptooth catfish (Clarias gariepinus), that is $65.9 \%$ (Nurhayati et al., 2013). The balance between the protein hydrophilic and lipophilic bonds is highly determinant of the protein emulsifying capacity (Chalamaiah et al., 2012). The factors affecting the emulsifying properties of protein hydrolysate are the raw material of the hydrolysate, the length of the peptide chain in the hydrolysate, and the degree of hydrolysis (Amiza $\boldsymbol{e t}$ al., 2012).

Bonylip barb protein hydrolysate flour is a development product from bonylip barb meat. It thus becomes important that the solubility of the bonylip barb protein hydrolysate flour be known. Protein solubility is the amount of sample protein solved within a solution. The value of the bonylip protein hydrosylate flour's solubility in water (neutral pH) based on Table 1 was $78.20 \%$. This value is smaller in comparison to that of the protein hydrolysate flour from African sharptooth catfish (Clarias gariepinus), that is 98.86\% (Nurhayati et al., 2013). Protein solubility is influenced by internal and external factors. Included as internal factors are the amino acid composition, protein molecular 
weight, and protein conformation. Meanwhile, included as external factors are the ionic strength, solvent type, $\mathrm{pH}$, temperature, and certain processing condition (Akhade et al., 2016). This property is closely linked to other protein functional properties, especially the emulsion property (Ramachandran et al., 2010).

2. Chemical characteristics of bonylip barb protein hydrolysate flour

The measurement results of the proximate composition of bonylip barb protein hydrolysate flour are presented in Table 2.

Table 2. Proximate composition of bonylip barb protein hydrolysate flour

\begin{tabular}{lc}
\hline Parameter & Proximate composition \\
\hline Water content & $8.75 \%$ \\
Ash content & $4.80 \%$ \\
Protein content & $84.65 \%$ \\
Lipid content & $1.02 \%$ \\
\hline
\end{tabular}

The protein content of the bonylip barb protein hydrolysate flour in this research (84.65\%; Table 2) is higher than that of the protein hydrolysate flour from African sharpteeth catfish (Clarias gariepinus) (69.26\%) (Nurhayati et al., 2013). But in comparison to the protein content of the protein hydrolysate flour from Nile tilapia (97.57\%; Foh et al., 2011), it was lower. The protein content of commercial fish protein hydrolysates generally ranges from $73 \%$ to $75 \%$ (Nurhayati et al., 2013). The differences in the protein content in fish protein hydrolysate flours are extremely influenced by the fish species, type of enzyme used, and drying method (Kristinsson and Rasco. 2010).

The bonylip barb protein hydrolysate flour in this research contained $1.02 \%$ lipid content (Table 2), higher than that contained in the protein hydrolysate flour from African sharpteeth catfish (Clarias gariepinus), that is $0.5 \%$ (Nurhayati et al., 2013), and lower than that contained in commercial fish protein hydrolysate flour, which ranges from $19 \%$ to $22 \%$. The measure of lipid content in fish protein hydrolysate flour will affect to a high degree the storage capacity.

The water content of commercial protein hydrolysate flour falls within the 3\%-5\% range (Nurhayati et al., 2013), while the water content of quality one commercial flour of fish protein concentrate (Dewita and Sahrul. 2015) and that of quality one commercial fish flour were both $10 \%$ at the maximum (SNI 01-2715-1996). The water content of the bonylip barb protein hydrolysate flour obtained in this research was $8.75 \%$ (Table 2). It is higher than that of the protein hydrolysate flour of African sharpteeth catfish $(3.45 \%$; Nurhayati et al., 2013) and silver catfish (5.93\%; Amiza et al., 2013). Compared with the water content in the protein hydrolysate flour from Nile tilapia (9.06\%; Annisa et al., 2017), the value is lower. Differences in the drying method and fish species are the main factors that influence the water content in fish protein hydrolysate flour.

Ash content is representative of the mineral content of a product. The ash content of the bonylip barb protein hydrolysate flour in this research was $4.8 \%$ (Table 2), which 
falls within the range of commercial fish protein hydrolysate flour ash content (4-7\%; Nurhayati et al., 2013). This value is higher than that of the ash content of the protein hydrolysate flour from silver catfish (4.45\%; Amiza et al., 2013) and that of the protein hydrolysate flour from cobia (4.73\%; Amiza et al., 2012). In comparison to the ash content of the protein hydrolysate flour from silver fish in another study (5.22\%; Abraha et al., 2017), the ash content of bonylip barb protein hydrolysate flour is lower.

3. Amino acid profile of bonylip barb protein hydrolysate flour

The amino acid profile of bonylip barb protein hydrolysate flour is presented in Table 3. The amino acid profile of Nile tilapia protein hydrolysate flour is also presented as a comparable (Foh et al., 2011).

Table 3. Amino acid profile of protein hydrolysate flours from bonylip barb and Nile tilapia

\begin{tabular}{|c|c|c|c|c|}
\hline \multirow[t]{2}{*}{ Parameter } & \multirow[t]{2}{*}{$\begin{array}{l}\text { Bonylip } \\
\text { barb }\end{array}$} & \multirow[t]{2}{*}{$\begin{array}{l}\text { Nile } \\
\text { tilapia }\end{array}$} & \multicolumn{2}{|c|}{$\begin{array}{l}\text { Essential amino acid } \\
\text { requirement per FAO } \\
\text { Standard }\end{array}$} \\
\hline & & & Child & Adult \\
\hline Aspartic acid (\%w/w) & 6.93 & 9.65 & & \\
\hline Tyrosine $(\% \mathrm{w} / \mathrm{w})$ & 2.63 & 2.06 & & \\
\hline Serine $(\% w / w)$ & 3.61 & 3.87 & & \\
\hline Glutamate $(\% \mathrm{w} / \mathrm{w})$ & 12.14 & 17.48 & & \\
\hline Proline $(\% \mathrm{w} / \mathrm{w})$ & 3.58 & 5.35 & & \\
\hline Glysine (\%w/w) & 5.11 & 4.44 & & \\
\hline Alanine $(\% \mathrm{w} / \mathrm{w})$ & 5.66 & 6.41 & & \\
\hline Cystine (\%w/w) & 2.19 & 0.56 & & \\
\hline Valine (\%w/w) & 3.84 & 3.96 & 2.9 & 3.9 \\
\hline Methionine $(\% \mathrm{w} / \mathrm{w})$ & 2.86 & 2.87 & 2.3 & 1.6 \\
\hline Ileusine $(\% \mathrm{w} / \mathrm{w})$ & 3.55 & 3.59 & 3.0 & 3.0 \\
\hline Leusine $(\% \mathrm{w} / \mathrm{w})$ & 6.16 & 7.67 & 6.0 & 5.9 \\
\hline Threonine $(\% \mathrm{w} / \mathrm{w})$ & 3.6 & 4.37 & 2.5 & 2.3 \\
\hline Phenylalanine $(\% \mathrm{w} / \mathrm{w})$ & 3.22 & 3.46 & 4.1 & 3.8 \\
\hline Histidine $(\% \mathrm{w} / \mathrm{w})$ & 3.31 & 2.01 & 1.6 & 1.5 \\
\hline Lysine (\%w/w) & 6.72 & 8.65 & 4.8 & 4.5 \\
\hline Arginine $(\% \mathrm{w} / \mathrm{w})$ & 4.81 & 5.71 & & \\
\hline Trypthopan (\%w/w) & 2.12 & 0.28 & 0.66 & 0.6 \\
\hline
\end{tabular}

Based on Table 3, the amino acid contents of the protein hydrolysate flours from bonylip barb and Nile tilapia were comparable. The essential amino acids contained in bonylip barb protein hydrolysate flour was excellent because they meet the minimum need of amino acids in children and adults alike as specified by FAO. Thus, bonylip barb protein hydrolysate flour is a recommended nutritional reinforcement or supplement to food products, both for children and for adults. 


\section{CONCLUSION}

The functional properties of water absorption, oil absorption, emulsifying capacity, bulk density, and solubility in water of bonylip barb protein hydrolysate flour scored $3.1 \mathrm{~mL} / \mathrm{g}, 1.94 \mathrm{~mL} / \mathrm{g}, 23.60 \%, 0.83 \mathrm{~g} / \mathrm{mL}$, and $78.2 \%$, respectively. The bonylip barb protein hydrolysate flour contained water, protein, fat, and ash at $8.75 \%, 84.65 \%$, $1.02 \%$, and $4.80 \%$, respectively. Bonylip barb protein hydrolysate flour can be used as a nutritional supplement or supplement to low-protein food products.

\section{ACKNWLEDGEMENTS}

At this pleasurable moment, I would like to genuinely thank 1) the Director of Research and Community Service of UniversitasPadjadjaran for the funds provided so that this research could be conducted successfully and 2) students of the Fishery Study Program of Universitas Padjadjaran, Nadia and Laili, for the assistance in this research.

\section{REFERENCES}

Abraha, B.; Mahmmud, A.; Samue, M.; Yhdego, W.; Kibrom, S. and Habtom, W. (2017). Production of fish protein hydrolysate from silver catfish (Arius thalassinus). MOJ Food Processing \& Technology., 5(4) : 328 - 335.

Akhade, A.R.; Kolo, J.M.; Sadawarte, R.K. and Akhade, R.R. (2016). Functional properties of fish protein concentrate extracted from ribbon fish, Lepturacanthus savala by different methods. International Journal of Processing and Post Harvest Technology., 7(2) : 1-9.

Annisa, S.; Darmanto, Y.S. and Amalia U. (2017). The Effect of Various Fish Species On Fish Protein Hydrolysate With The Addition of Papain Enzyme. Indonesian Journal of Fisheries Science and Technology., 13(1) : 24-30.

Amiza, M.A.; Kong, Y.L. and Faazaz, A.L. (2012). Effect of hydrolysis on physicochemical properties of cobia (Rachycentron canadum) frame hydrolysate. Journal International Food Research ., 19(1): 199-206.

Amiza, M.A.; Ow, Y.W. and Faazaz, A.L. (2013). Physicochemical properties of silver catfi sh (Pangasius sp.) frame hydrolysate. International Food Research Journal., 20(3): 1255-1262.

Atmaka, W. and Sigit, B.A. (2010). A Study on Physicochemical of Instant Flour Several Corn (Zea mays L.) Varieties. Jurnal Teknologi Hasil Pertanian., III(1) : 111 
Chalamaiah, M.; Hemalatha, R. and Jyothirmayi, T. (2012). Fish protein hydrolysates: Proximate composition, amino acid composition, antioxidant activities and applications: a review. Food Chemistry., 135(4) : 3020-3038.

Chandra, S.; Singh, S. and Kumari, D. (2015). Evaluation of functional properties of composite flours and sensorial attributes of composite flour biscuits. J Food Sci Technol., 52(6) :3681-3688.

Dewita and Syahrul. (2015). Quality assessment of fish protein concentrate from catfish (Pangasius hypopthalmus) during storage at room temperature. IOSR Journal of Environmental Science, Toxicology and Food Technology 9(9) : 20-23.

de Santos, S.A.; Martins, V.G.; Mellado, S. and Prentice, C. (2016). Evaluation of functional properties in protein hydrolysates from bluewing searobin (Prionotus punctatus) obtained with different microbial enzymes. Food Bioprocess Technol., 4:1399-1406.

Foh, M.B.K.; Kamara, M.T.; Amadou, I.; Foh, B.M. and Wenshui, X. (2011). Chemical and physicochemical properties of tilapia (Oreochromis niloticus) fish protein hydrolysate and concentrate. International Journal of Biological Chemistry., 5(1) : 21-36.

Halim, N.R.A.; Yusof, H.M. and Sarbon, N.M. (2016). Functional and bioactive properties of fish protein hydolysates and peptides: A comprehensive review. Trends in Food Science \& Technology., $51: 24-33$.

Haryati, S.; Sukarno; Budijanto, S. and Prangdimurti. E. (2020). Characterization of functional properties catfish protein isolates (Clarias $s p$.). International Proceeding Earth and Environmental Science., 404 : 1 -11.

Kaushal, P.; Kumar, V. and Sharma, H.K. (2012). Comparative study of physicochemical, functional, anti-nutritional and pasting properties of taro (Colocasia esculenta), rice (Oryza sativa), pegion pea (Cajanus cajan) flour and their blends. LWT-Food Sci Technol., 48:59-68.

Kristinsson, H.G. and Rasco, B.A. (2010). Fish protein hydrolysates: production, biochemical, and functional properties. Critical Reviews in Food Science and Nutrition., 40(1):43-81.

Lee, H.J.; Park, S.H. and Heu, M.S. (2016). Chemical composition of protein concentrate prepared from Yellowfin tuna Thunnus albacares roe by cook-dried process. Fisheries and Aquatic Sciences 19(12) : 1-8.

Mohammed, G.F.; Sulieman, A.M.; Soliman, N.G. and Bassiuny, S.S. (2014). Fortification of biscuits with fish protein concentrate. World Journal of Dairy \& Food Sciences., 9 (2): 242-249. 
Nesse, K.O.; Nagalakshmi, A.P.; Marimuthu, P.; Singh, M.; Bethariya, P.J. and Ho, M. (2014). Safety evaluation of fish protein hydrolysate supplementation in malnourished children. Regulatory Toxicology and Pharmacology 69 : 1-6.

Ntau, L.; Sumual, M.F. and Assa, J.R. (2017). The Fermentation Effects of Lactobacillus casei to Sweet Corn Physical Characteristic. Science and Food Technology Journal., 5(2) : 11-19.

Nugroho, E.; Sukadi, M.F. and Huwoyon, G.H. (2012). Several types of potential local fish for cultivation. Media Akuakultur., 7(1) : $52-57$.

Nurhayati, T.; Nurjanah and Sanapi, C. H. (2013). Characterization of Protein Hydrolysates from African Catfi sh (Clarias gariepinus). Indonesian Fisheries Processing Journal., 16(3): $207-214$.

Ramachandran, D.; Mohan, M. and Sankar, T.V. (2010). Effect of thermal modification on physico-chemical and functional properties of myofibril proteins from tilapia, Oreochromis mosambicus. Journal Fish Technol ., 47(1) : $41-50$.

Rieuwpassa, F.J.; Santoso, J. and Trilaksani, W. (2013). Characterization of functional properties fish concentrate of Skipjack Roe (Katsuwonus pelamis). Jurnal Science and Tropic Marine Technology Journal., 5(2) : 299-310.

Rostika, R.; Andriani, Y. and Junianto. (2017) Fecundity performance of nilem (Osteochilus vittatus) from Cianjur, Tasikmalaya and Kuningan Districts, West Java, Indonesia. Asian Journal of Agriculture., 1(1): 17-21.

Standart National Indonesia, Number : 01-2715-1996. (1996). Fish meal Natioanl Standart. Indonesian National Standards Agency, Jakarta.

Syamsuri, A.I.; Alfian, M.W.; Muharta, V.P.; Mukti, A.T.; Kismiyati and Satyantini, W.H. (2017). The Grow out of Bony barb (Osteochilus hasselti) In "Center for Gurame and Bony barb Stock Development and Controlling, Tasikmalaya, West Java. Journal of Aquaculture and Fish Health., 7 (2 ) : 57 - 62.

Taheri, A.; Anvar, S.A.A.; Ahari, H. and Fogliano, V. (2013). Comparison the functional properties of protein hydrolysates from poultry by-products and rainbow trout (Onchorhynchus mykiss) viscera. Iranian Journal of Fisheries Science., 12(1) : $154-169$.

Villamil, O.; Váquiro, H. and Solanilla JF. (2017). Fish viscera protein hydrolysates: Production, potential applications and functional and bioactive properties. Food Chemistry., $224: 160-171$.

Wani, I. A.; Sogi, D. S.; Wani, A. A. and Gill, B.S. (2013). Physico-chemical and functional properties of flours from Indian kidney bean (Phaseolus vulgaris L.) cultivar . LWT - Food Science and Technology., 53: 278-284. 